\section{ANTHROPOLOGICAL PERSPECTIVES ON GRASSROOTS DEVELOPMENT IN NEPAL ${ }^{1}$}

\section{Padam Lal Devkota}

\section{ABSTRACT}

Much has been written on rural problems within Nepal and even more on Nepal's rural poverty. Many research studies have been conducted and recommendations made for improving the quality of life of the rural poor. But the gap between rich and poor is increasing at an even faster rate than the number of Rural Development Projects in the country and research reports in the librarics.

Reviewing the rural development measures undertaken in Nepal, a certain pattern emerges: targets set, strategy worked out, implementation under way, impact studies completed, reports prepared. How much is actually achieved or sustained often remains a secondary consideration.

I first became associated with this project while working in the field in a participatory rural development program in a Nepali Village. I've observed some wonderful things happen during this project, and I've lived through confrontation and frustration. I want to share these experiences with you through this paper.

I've been involved as villagers have become articulate in communicating their planning needs and concerns. I've been excited as I've seen deal with these issues. But I've also shared their dissatisfaction and disappointment as the struggle for development in rural Nepal continues.

I believe development anthropologists have a challenging role to enable the poor and powerless to look at their world differently and to help them develop the capacity for self-help, either individually or collectively, in the long term. This goal can obviously be achieved neither by the national policies of centralizeddecentralized development nor by research reports written on rural poverty. What is required is a commitment on the part of development anthropologists to immerse themselves in the quest for the causes of rural poverty. Through the practice of learning by doing a successful process emerges. This process is not in itself a ready-made package for development, prepared without the people's input or the researcher's predictions of problems. The process is the product of the people's own knowledge and action: their effort to look critically at the world in seeking to overcome the present injustice that prevails.

\section{INTRODUCTION}

This is the story of my work from June 1988 as Community Facilitator in a rural health development project undertaken in the village of Mehelkuna in the district of Surkhet in the Mid West Region of Nepal. During this time I was employed by the Nepal Health Development Project (HDP), a collaborative project between the University of Calgary and the Institute of Medicine at Tribhuvan University in Nepal. The HDP is funded by the Canadian International Development Agency (CIDA) over a seven year period, 1987-94.

The overall project purpose is:

"To strengthen the capacity of government health institutions and rural communities in Surkhet District to meet health needs through community-based participatory development, management strategies, and the training of generalist physicians."

My role has been to work with groups to develop their capacity to analyze their own priority problems and to identify and access resources to meet health and other needs. I have seen some wonderful things happen since 1988, and I would like to share my experiences with you.

Nepal is one of the world's poorest countries, with a GNP of US\$180 (1988). During the period of $1980-88,55 \%$ of its urban and $61 \%$ of its rural population were below the level of "absolute poverty." Nine percent of the population were below the lillion is urbanized, with an annual average urban growth rate of $7.2 \%$. The overall population growth is $2.6 \%$ per annum, with a growth rate of $7.2 \%$. The ove expectancy of 50 years. The central government fertility rate of $5-8$ and a health is $4 \%$ compared to $11 \%$ for education. For the expenditure allocation to health is $4 \%$ comparban populations had access to safe drinking water, but only $25 \%$ of the rural population.

As these statistics show, there's a large discrepancy between standards of living in rural and urban areas of Nepal. This being the case, many have 
undertaken research studies and/or written papers making recommendations for improving the quality of life of the rural poor. But the gap between rich and poor is increasing at an even faster rate than the number of Rural Development Projects in the country and research reports in the libraries.

Mehelkuna is an area newly settled during the last 25 years since spraying reduced the area's malaria risk during the mid- 60 's. People of several ethnic and caste groups moved into Mehelkuna from the surrounding hills and cleared the land. The lack of any effective irrigation means that their yields of rice and winter wheat are declining. Consequently Mehelkuna is only self-sufficient in food for 3-4 months per year. It is thus described as a food deficit area.

\section{DEVELOPMENT ANTHROPOLOGY AND PARTICIPATORY RESEARCH}

Anthropologists work in an academic environment teaching, studying and completing research projects, or in the field, as applied anthropologists. Development anthropology is another form of applied anthropology.

Participatory Research is the study of effective involvement in the development planning process. By virtue of their long-term commitment and training and skills in participant observation, in in-depth semi-structured interviews, and in successful rapport building, field workers can contribute to community development and participatory research. Many anthropologists now apply anthropological knowledge and methods to elicit practical and effective responses to the realities of community need.

Many international aid programs and large projects hire anthropologists in hopes of promoting community participation within the development process. For with their experience in the culture and society, anthropologists can become development agency "watchdogs," responsible for keeping an eye on development projects. They gain insight into socio-cultural realities and, can identify development issues because they possess skills in presenting data, advice and recommendations to the relevant organizations. Involving anthropologists in development programs indicates not a belief in success but the deeply rooted fear of failure.

The Development of Development Anthropology in Nepal

Historically, anthropology in Nepal has moved from a romantic-orthodox approach to one with more emphasis on social change and development-oriented teaching and research. The Center for Nepal and Asian Studies (CNAS), a pioneering research institute of sociology and anthropology within the Tribhuvan University, has attracted many competent sociologists and anthropologists. Each year the Center undertakes more and more research work. The previously empty library shelves are now filled with books and reports. Research projects are undertaken on the latest issues and concepts and reseachers busily adapt new themes, ideas, models and methods from books and articles written mostly by Western scholars.

But those suffering from hunger, landlessness and other socio-economic to address the people's basic needs find no comfort in the increasing number of research projects and professional practitioner at CNAS. Their surveys on poverty, self-reliance and income, for instance, ask irrelevant questions about the productivity and income of people who have suffered generations of hunger and poverty. What's more planners lack time to read research findings, professional philosophy, a workable approach or even an intention to be a humanitarian partner in Nepal's emancipation.

Nepal needs well trained applied anthropologists as well as academic anthropologists to reverse this trend. But currently that training is not available.

For instance, TU'sCentral Department of Sociology/Anthropology opened on the Kirtipur Campus in 1981. While I am in no position to comment on how it functions, I can describe the institution's physical learning environment. More like a cowshed than a classroom, dialogue during the rainy season is almost impossible under the tin roof. Broken chairs lie piled in the corner of a classroom. And the Department Chair's telephone rarely works. There's no budget for repairs. Nor funds are available for conducting independent research. This lack of funding naturally limits the training of both academic and applied anthropologists. A mere $25 \%$ of enrolled students attend classes regularly. The remainder show up only to submit internal assessment papers or to fill out registration forms just before the final examination. Senior professors continue to exert their influence and academic biases. There is litle evidence or real participation or self-reliance. The salaries and benefits provided by the faculty are so low that teachers spend their time research how to get loans to feed their families.

I believe that the whole academic milieu requires an overhaul. Ironically a lack of bribery and corruption on behalf of education has meant that there's been little investment of national resources in anthropological education in Nepal. 
This lack of funding has undermined morale. No one can be a good scholar when there are no incentives to do good work.

\section{Participatory Research in Nepal: Concept and Practice}

Although new to Nepal, participatory research has been accepted rapidly and practiced within various rural development projects. It is seen as an important vehicle to gear people's participation through an already structured development program in a fixed socio-policital system. Unfortunately participatory research in Nepal has not been recognized as a means to transform the existing socio-economic reality but has instead been used to maintain the existing development strategy. The major purpose has been to continue fitting people into the existing socio-political machinery, not to facilitate them in transforming it according to their will.

Several grassroots based development projects do exist: the UNICEF/WDS "Production Credit for Rural Women Project" (RIDA 1989:51), the Agriculture Department's "Agriculture Extension Program" (Devkota 1989:10), the Department of Forestry "Community Forestry Development Project" (Griffin 19889:20) and others (Gilmour and Fisher 1991). Unfortunately their programs do not emphasize involving the people in the process, so people do not feel that the projects belong to them. These organizations deliver goods without consulting the beneficiaries.

Many of these programs, because of fear and threat of failure, seek support and acceptance from the rural elites (both the formal and informal leaders). This leads to participatory research's approach, method and techniques being misunderstood and poorly implemented. It also provides more opportunities for the educated and wealthy to manipulate power, resources and the people themselves.

There are good participatory projects in Nepal. The Nepal/Australia Forestry Project, for instance, and the Integrated Development System "SelfReliant Development Program" (IDS 1989:9) and the ADB/N "Small Farmers Development Program" (ADB 1986:3). These function well because they pay more attention to involving people into the process, into decision-making and planning. Community-based programs actually go into the villages and try to talk with the people about the best strategies for dealing with local issues. Although not based in the community they are in close contact with the people and they have extension workers operating in the villages communicating with the rural poor.

\section{NEPAL'S DEVELOPMENT EXPERIENCE ON TRAIL}

"Dhani lai vikas ayo Garib lai kam ayo." (Development comes for the rich, work comes for the poor)

- A Ramghat Woman.

Nepal has seen a regular increase in new project investment, and in the numbers of administrative staff in development programs and surveys in the countryside. However there has been little improvement in the quality of life, in countryside. However there has been little improvers. Although Nepal has tried many development models borrowed from many countries, including both capitalistic and socialistic, our development experience has shown that what works elsewhere does not necessarily work here. One reason is that the flow of works elsewhere does not necessarily work here. One reason is thach or benefit the grassroots. Rural people still suffer from poverty, hunger and social injustice. As a result many project feasibility studies show that the people have lost their faith in development imposed by the central government.

Subsequently, in 1990 Yadav made an attempt to classify Nepal's Basic Needs, using two broad levels:

1. Physiological: food, clothing, shelter.

2. Essential services: safe drinking water, sanitation, public transport, health and education facilities.

Taking Basic Minimum Needs into account, many sectorial and subsectorial programs have been sketched to strengthen both the productive and the social sectors. Designed and then included in district and national level plans and policies they were aimed to enable the poor to purchase essential goods and to policies they were aimed to enable the poor to purchase essential goods and clothing, housing, education, health, security, employment, distribution and finance for change.

Despite the numerous national and international workshops organized and attended by planners and policy-makers to review, clarify and conceptualize the basic needs concept and context, this development strategy has also failed. For once again the development benefit has not gone to the poor but to the educated alliance of professionals, middle and upper-classes who live in the over populated urban areas. 
Nepal requested that the bulk of foreign aid be provided to support and implement Nepal's BMN program. Since then many surveys have been conducted and reports have been written. The result of this work, however, was rendered useless by the Basic Need Task-force formed in the country.

What is more rural people know only the slogan of the BMN program. How "to lead a life with human dignity by A sian standards," by the year 2000 was never clearly explained, much less effectively implemented. People perceive the BMN as a dream, gone on waking. Although the program was promoted throughout Nepal, villagers have seen nothing happen. Consequently they are today so antagonistic towards the Basic Need Program that one hesitates to introduce the subject. When someone accidently does, people laugh and speak of "adhar" and "bhut" (literally, "base" and "ghost"): the "base" has gone and only the "ghost" remains.

In Nepal many terms describe planning: Planning for People, Planning to People, Planning with People, Planning by People. But the performance of the plans shows that there has never been a commitment to people-based planning. People-based planning encourages people to be upstanding and self-reliant through their own initiative and aspirations. It helps people to look critically at their total environment and to acquire the skills needed to unite, organize and plan improvements in the quality of their lives through their own local popular organizations.

The rural poor need a place where they can present their ideas and interests, and be heard. Those projects that operate in Nepal outside the political system function well. Examples are: the Nepal/Australia Forestry Project, the Small Farmers Development Project, and the Dhading Development Project. These receive direct input from the community in both their development and implementation.

Often as planners we interact with the structure, with the framework rather than with the beneficiaries. We consider how many people should be belonged on a project, and what class of officer they should be. we become lost in the organization, rather than in interaction with the people. When the management structure operates at central, regional and district levels, but not at the place level, how can you interact with the people?

Sometimes the planning is so poor that even the most needed thing in a particular region, such as drinking water, is not provided. Politicians may not consider it a priority. One top planner has said: "There is no planning in Nepal at all" (Shrestha 1989). Whatever exists on paper is but a "guessing game".

This guessing game exists because planning in Nepal has always been imposed from above and hidden in the files of planners and bureaucrats rather than in the minds and hearts of the people. I believe that development planning cannot be imposed from the top down. "Source-force" works against it. This refers to the network of relationships between the lower and upper middleclasses, or between ethnic groups, or castes. While self-interest groups place their own people into positions of power development planning cannot function equitably. The Nepali value system, for instance, affects the accessibility to power by supporting the caste hierarchy. Chakari relationship built on the philosophy of "I will wait to see the person in power", and 'afno-manche' closed power networks all work against the rural villager, who has no such influence.

People's participation has been recognized as a principal development mantra for rural development but paternalism has dominated popular wishes. Foreign agencies give money and power to people within the existing infrastructure, and they make themselves more influential, more powerful as they determine where the money should be spent. The end result has been that people's participation has almost lost its meaning while all the power remains at the central level (Uphoff 1978:71).

The evidence shows that every "revolutionary step' was systematically ignored as development programs were imposed from the center. Thus, success can hardly be claimed on any front. What is needed to change the whole system is a process based on the critical discovery of the people's own praxis and quest to transform.

\section{DEVELOPMENT AT THE GRASSROOTS : LOOKING FROM BELOW}

"Everybody in the town here says, the Bahudal (multi-party) has come to the country. But I do not know when it will come to our remote villages."

- A villager from the remote district of Jumla in Birendranagar bazaar.

Development is a sensitive issue in Nepal. It is the easiest to obtain when perceived narrowly, as the delivery of resources or commodities from the center to the periphery. If the system wants to give development to a certain area, it provides services with no thought of process or channel. If the system does not 
want to deliver however, people do not receive. Nor do they ask for development for they do not know how.

Inevitably in most cases people do not know what kind of project will be imposed on them. What is certain is that lacking prior discussion regarding need, priority and implementation policy, they will not receive quite what they expected or requested. For this reason social planning has not meaning for rural people. They are not involved and accountability is far away. If they were involved, if they understood the development process, and had input, they could communicate their development needs and concerns through the proper channels. Then the issues would change.

But for now no means exists for public debate on how, where, why and who should benefit from development aid. Rather, the typical process revolves around the central political structure which operates from center to region to district but not to the place actual level. That system becomes stronger and the powerful become more powerful.

For example many villagers only learn of a project when a development agency employee makes his first visit to the site. For instance a survey team may come to ask the formal leaders about possible sources of drinking water. The leaders offer many extension and technical workers, accommodation in their homes and then direct them according to their wishes.

Bearing this in mind, I was assigned to work at the place level. My role has been to involve the poor in debate about their own development, and to help them learn skills necessary for discussion for change and development. When the people are capable of analyzing their own situation, and participating in development debate, they can express their own ideas and organize themselves to ask for development.

The rural community experience and perception of "development" is largely limited to projects coming from above, from the district and central levels. Subsequently those projects that have been completed at the grassroots are frequently perceived to belong to others rather than to themselves (Devkota 1988:8). This is understandable when outsiders not villagers make money or find employment from these schemes. And organizations away from the place level not only plan but manage, and monitor the projects, usually without consulting the people.
The following illustrates how the development system operates at the micro level. For ten years Mehelkuna villagers sought funding to construct an irrigation system. They went through all the required processes and correct bureaucratic channels, but never received the necessary money. This was not because the scheme was unnecessary, but due to a weak village leadership that was unable to challenge the system's decisions.

Elsewhere in Surkhet, in the village of Gutu, the people misdirected a survey team for a drinking water project because the local people did not want the source chosen by the District Office to be used for drinking water. They had used this source for irrigation for many years and feared their farming practices would be threatened where it to be used for drinking water.

In nearby Ramghat villagers had been requesting an irrigation canal but they received instead a small drinking water project. They did not refuse, feeling lucky to get anything at all after waiting for so long. If they had said no, they would have received nothing.

These experiences reflect how development in rural Nepal often occurs through chance and uncertainty.

"People wait for good things to come, but nothing comes here except the worst."

- An anti-panchayat school teacher.

The Decentralization Committee, established as early as 1964, has objectives that villagers and their leaders still do not clearly understand. The principles and policies of decentralization look impressive on paper but have not been passed on to villagers in practice. Local development in the name of "self help" and people's participation has received lip-service only. As one village leader, discussing HMG's decentralization policy, stated: "We don't know leader, discussing HMG's decentralization policy, 'drink water' " (Devkota 1988:19).

An old man in Mchelkuna who became sufficiently aware and confident to speak at one of the community meetings commented:

"You see, development is more or less like a tree, but we only see the top of our development tree without a trunk. I wonder how the top could survive without a strong trunk." 
This wise gentleman's metaphor exposes his understanding of the rootless decentralization and decision-making at the top, as compared with the real need to strengthen development at the grassroots, at the village level.

A Tharu woman also became quite articulate after a few months of participatory leadership training. She gained an understanding of the planning process and asked meaningful questions, such as when she grumbled before the video camera:

"Development never comes, so we can't bring it.I do not understand why the many people of our village can't bring development."

This woman was not referring to the delivery of development per se, but was directing her comment to the strength of her fellow community members literally empowerment.

Nepal's development has operated in a "trickle-down" process from centre to region to place levels, rather than being firmly grounded in popular action and reflection. As a result the people, like the state, see development as synonymous with road construction and the digging of irrigation ditches, all supported by foreign aid projects. Development has become merely a commodity delivered from superiors to inferiors for there is no structure for development to be planned at the grassroots level. Since the people have no experience of grassroots planning, they have no understanding of how to start the process. There are no local initiatives and no people's involvement in the development process.

Instead they ask for what they may receive. In the Surkhet District nearly $75 \%$ of the village assemblies have asked to be included in the K-BIRD project, requesting this kind of community oriented project. K-BIRD is the largest Canadian-funded Integrated Rural Development Project for mid-western Nepal, especially responsible for strengthening the existing development infrastructure.

According to Bhave the required influence and power can only be developed by involving people in participatory training where they acquire the critical skills and education necessary to deal with changing experiences, either individually or collectively (Bhave 1986:23). A local people's organization could at least work to alter the system responsible for injustice, inequality, ignorance and lethargy. They not "it," would be accountable.

\section{GRASSROOTS DEVELOPMENT STRATEGY : A DEVELOPMENT TOKEN}

In reality, the concept of people's participation has been restricted to the voluntary labour contribution (APROSC 1986:62). The government philosophy is to "mobilize" people, as if the people are another development commodity. "Mobilization" is misunderstood as being participation. I believe that we do not need to mobilize people. We need to involve them. Villagers are typically treated as development mules to dig the roads, carry the pipes and the cement. If they become participants, they not only dig roads, lay cement etc. but they play a continuous role in the process of planning development for their village.

The history of Nepal's development planning has moved from District Plan, local development program, IRDP and other multi-sectorial programs, but the pace of implementation, especially at the grassroots level, has not improved significantly. Past experience reveals that many sectorial programs remain quite unsatisfactory. Pradhan's review of rural development programs shows that they all suffer in implementation (1985:42). I submit that many of the problems that occur in planning, in structure and in implementation arise because the people have no understanding of how the system works.

The so-called "social planning process" detailed in government documents under the previous panchayat system makes no sense when implemented. On behalf of the whole village, the community leaders, sitting in the local tea shop, seek the assistance of a school teacher to draft a village planning document in the prescribed official format and language. The teacher is brought in only because he can read and write. He has no basic skills in place planning. The village messenger then collects the villagers' thumb prints and submits them to the village assembly. With no discussion or debate, the document is approved and submitted to the district planning unit for further action. In most cases, the same process is re-entered every year as non of the projects the village has requested in the past five years have yet appeared (Devkota, 1989). For usually not even the leaders have training in how the place development process operates. The people are patient however, and will try and try again.

Once the document reaches the district planning unit, it must compete against the other villagers' requests. The leaders and others with more access to central power, personal relations, political accessibility, source-force or exposure to the functioning of the system (i.e. knowledge of the structure and function of the politico-development system) remain the most successful in accessing the development resources. 
The 1990 movement for the restoration of democracy has certainly increased popular expectations for social, economic, political and administrative reforms. It is the right time to establish new administrative machinery for development to meet people's basic needs and aspirations for an improved political system. Efforts at such change should be guided if possible by peaceful means in a democratic environment.

The Government has misunderstood mobilization for participation. Mobilization means bringing villagers to work on projects. Participation starts much earlier. Villagers help plan projects and have a voice in determining which projects are undertaken.

The current structure of development planning mirrors the political infrastructure within Nepal. I believe that the present machinery needs to be reviewed the replaced with a system Nepal. I believe that the present machinery needs to be reviewed and replaced with a system that operates not only at the center, region and district levels but at the place assembly level also.

\section{Outreach Services}

"A signboard alone help people. The extension workers must have a sense of dedication, a service moti ve and honesty."

- A wise old man of Kunathari village.

Theoretically Nepal follows a concept of integrated service between the center and the rural communities. Development expanded rural services in one of the key goals of Nepal's rural development planning. Attempts are being made to put the concept into practice by establishing Rural Service Centers in each Ilaka of the district, under district level development offices and organizations. But the concept of integrated service neither integrates services at the grassroots level nor affects the district, regional and national level target setting and planning processes. The reason is that this strategy suffers from ineffective coordination, management and implementation (Acharya 1986:90).

There is a serious problem of coordination at the district level among various line agencies and among the local development organizations. They have no direct link between their departments at district or regional or central levels. Their managements operate in differing structures and in differing styles, so inevitably their development implementation varies as well. Even the physical location of the Rural Service Centers reflects the problem of providing an integrated service. Location is more of ten setuled as a matter of political dispute than because of its equal accessibility to its beneficiaries.

Nor are most extension programs operated by service centers (or other extension programs) community-based (Devkota 1988). The Government imposes services and programs on the beneficiaries to meet its ready-made package of set targets. For instance, too often the district center totally changes programs and targets set by the village extension worker. Thus local needs are ignored in favour of so-called national priorities.

Self-reliance is a major development objective with implementing agencies, such as the SFDP, WDS, IDS and DDP/GTZ have tried to develop through poverty group ranking strategies. Significant results have not, however, been achieved. Placing "mediators," "brokers," and "matchmakers" as liaison between the village and district agencies is a good idea, but in reality these have only increased local expectations and dependency. The "middlemen" keep busy meeting set targets to produce tangible results rather than undertaking social mobilization for empowering the powerless.

In my opinion, the people will never be empowered to improve their critical awareness of development, nor their level of confidence and self-reliance by this kind of dependency approach. Instead this sort of malpractice creates local dependence on outsiders. Most poverty group ranking programs lack a strong base. This leads to local misunderstanding of their purposes.

The process is not only inefficient but often corrupt. One example is that the user groups formed in the name of so-called "people's organization" are listed in reports and graphs enabling planners and administrators to show donors that development has happened, if not in the village, at least on paper. This enables dishonest technocrats and bureaucrats to continue their suppression of the people.

In addition, the meaning of "community participation" and "self-help" have been explained narrowly so that the people will provide the projects with free labor. The local power elites utilize this misunderstanding for their own interests, increasing their wealth by mobilizing voluntary labor. After long involvement in the dialogue process at place level, villagers identified the following causes they considered responsible for the failure of earlier types of community extension services: 
1. Most of the extension programs are directed by the individual interest of some influential persons rather than by the interests of the community as a whole.

2. The programs are imposed on the people from above without prior consultation or discussions.

3. Communication between the extension workers and the villagers about the extension service is lacking.

4. Individual effort to overcome problems is emphasized more than organized group effort.

5. Too many political factions exist for small scale community development to occur.

6. The local leaders push their own interests rather than listening to the people.

7. The extension workers feel superior to the people and hesitate to sit with, listen to and learn from them.

8. Inappropriate procedures, not including consultation with the community, are followed in the selection of village level mobilizers, workers and volunteers.

Outreach Services and Rural Service Centers are intended to help integrate village communities with the center. But the function of all the extension services is geared to target bounded action. These targets are established outside the community, and so make a dynamic partnership between the people and the extension service impossible.

Further a lack of links between departments and between organizations means that coordination is very difficult. For instance, the rural service centers at the place level have a veterinary office, an agricultural service station etc, but no formal communication network between them.

The end result is that an individual household's utilization of services still depends on its relationship to various physical, economic, social and political factors (Blaikie et al. 1979:80). The Basic Needs Approach has not benefited the poor (Blaikie 1979:81) nor sticceeded in transforming the society and the economy from below.

\section{The Development Phantom : People are Still Waiting}

"We need vikas (evolution/development). People coming from mathi (district level/central level) should give us vikas.... Anything that comes from mathi is vikas."
In my father's time villagers used to gather together to discuss social problems and to resolve them. They might decide to dig a road or repair a water well, or build a temple. The place level functioned socially and culturally. Now that development aid agencies exist, the people no longer bother trying to solve their own issues. Instead they say: "The government will help," or "the foreigners will come".

The problem is that development never comes, or at least not in the form that is needed. Instead of power being viewed as both source and product of the broad development process (Korten 1986:1), it has been confined to certain hands within Nepal's development structure. The cultural empowerment process based on the understanding of mutuality has been lost and replaced by the selfcentered self-interest. Social cohesion has been disrupted in the name of development and institutionalization. Stratification and economic disparities have become widespread. For the people have lost their concern for their community, for the welfare of others. They think only of themselves, of their employment, of their families and friends.

Subsequently through the actions of local power brokers and moneylenders, popular strength declines. For these groups control the development machinery and organization. People must depend on their leaders for their development. The elites are the source of information and decision making, and in many cases are seen as community change agents.

These formal leaders and local elites provide their knowledge about development, not to transform the "on-hand" social, economic and political structure, but to continue it in order to obtain more power from both the people and the state. In most cases their description of development does not reflect the popular aspirations but is based instead on maintaining their own power and the status quo. The state lacks the will to change this situation to liberate the masses.

The local power structure is not easily understood or analysed. It has both direct and indirect relations with district and center. Local power is affected and determined by district power, and this in turn by center power. Even after the restoration of democracy, the Palace remains the source of ultimate power in Nepal. The power structure is determined by many factors, such as interpersonal relationships, family affiliation and accessibility to the power base following ethnic and regional groupings. The village elites remain the key people in the flow of information to the top, in the maintenance of local security, iil politics and in influence-peddling. In the actual exercise of national-local policy and development, the communication flow remains top-down. 


\section{THE BLUEPRINT OF DEVELOPMENT : WHEN TO END?}

"Sarkar ko kam kahile jala gham."

"(Government work is waiting for the sun to set)."

- A Nepali proverb

Korten defines the blueprint of development as the series of steps involved in careful pre-planning before the development program is undertaken (Korten 1980:177). My concept of blueprint development is less broad and is based on the villagers' micro level experience when dealing with local and district level officials. The concept of "blueprint development" as used here is equally concerned with the contents of the policy papers, even if un-implemented, and with their effects on the recipients.

In many government offices throughout Nepal, of ficials treat the citizenry as inferior beings. Underprivileged and simple village people are overawed in the presence of government officials and try to use the Palace language (even thought it is unfamiliar) to impress them, in hopes of expediting their requests. Villagers must wait for several days to obtain one signature, and are often verbally abused by the officials. Many steps must be completed at the government offices and some allocate special days to particular work. Villagers may be unaware of this, and must therefore wait in the local bazaar where food and accommodation are expensive. The process of buying and selling land for example, takes at least 3 to 4 days and people have to return frequently to the same desk.

Village education is not compatible with the administrative process. Consequently professional writers (lekhandas) are always available around the court and district land revenue offices, of ten in greater numbers than their clients. The blueprint approach blocks the human sense of respect as the individual must manipulate the system rather than finding it a self-regulating administrative structure.

What is more, cases filed against sociocconomic injustice and deprivation lie lost in office drawers unless one can provide bribes or evidence of accessibility to the source-force (Weiner 1989: 669).

\section{CONCLUSION}

For these reasons, local people have not perceived development as their right to demand local and state power. They receive it as a gift from development teachers.

These and many other factors indicate that in Nepal development is processed, practiced, measured and even purchased, by paper. It is centered neither around people's basic needs nor around a broad national interest. It has been taken up as a slogan and a kind of propaganda by middle class bureaucrats to consolidate their own power and to gather more material wealth in the name of so-called "people-oriented development".

When top level officials visit the countryside to assess development progress, they are lost among these same rural elites. And the files of applications of the poor continue to proceed through these village leaders. This is not because people want to maintain the status quo with these leaders, but because this is the only way they can get a piece of the blueprint that carries demands to provide cement, pipe or other small scale village level projects.

Thus, unless the local power structure changes, rural development will remain meaningless. Such change could effect the country's entire governing system (Pandey 1989: 3).

Many other examples exist as well, compelling the conclusion that when put into this feudo-bureaucratic framework, even the most successful programs have failed to win over the people (Devkota 1985: 117).

I submit that the present power structure must be overturned in order for the grassroots to achieve self-reliance and sustainable development. This can be done by introducing the participatory process in rural development ventures. Such a process will empower the people. It will enable them to develop the confidence to take responsibility, ownership and control of development resources from the hands of government machinery into the hands of their own needsbased organizations.

The illusions developed by the power elites to hide development realities have compelled people to wait for development from above. This process will continue unless the poor and powerless can understand and analyse why and how they are forced to accept such an unjust reality.

I believe that the development anthropologist's role should be the study of powerless people's concerns, i.e. how to facilitate their liberation from poverty, repression and hunger by organizing them through their own popular 
groups. It seems to me that anthropologists of ten devote their intellectual energy to investigating problems but rarely take interest in solving them. We should be aligning anthropological research with a more pragmatic approach, using participatory methods to develop and strengthen community-based programs which are created by and reflected through the people. For then the people themselves step in to create development theory and gain control of the total development process.

This kind of approach in which the people themselves analyze their life experiences is "dialogue in development" and requires great patience on the anthropologist's part. He must listen and learn from the people, must share their experiences and work with them. In this way the people become able to relate to prevailed groups, and to create or adapt their organizations to alter the total system responsible for the existing ignorance, poverty, exploitation, social injustice and repression.

Development planing cannot be imposed. It is like trying to spoon feed a baby. A mother treis to give the baby more because she feels the baby needs something nutritious, but the baby is not interested, and spits it out. You cannot tell the rural poor "this is good for you, you must take it." It does not work.

\section{FOOTNOTE}

1. The author wishes to thank Prof. R.R. Regmi, Prof. G.S. Nepali, Prof. K.N. Pyakuryal, Prof. C. Mishra, Prof. Melville G. Kerr, Prof. Sheila Robinson, Prof. Bhishma Raj Prasai and Prof. H. Sloane Dugan for their moral and professional support in bringing this work to its present form, Dr. Donald A. Messerschmidt, Ms. Susan C. Beaton, Ms. Barbara Kermode-Scott for their help and useful suggestions, and Ms. Jean garsonnin and Mr. Kalusing Karki for their comradely during the participatory research project. The author is also obliged to Mr. Naveen P.J. Shah, Mr. Arjun Dewan and Mr. Dinesh Bomzan for their help in providing the necessary financial and administrative support during the Participatory Research process in Mehelkuna. Especial thanks go to the people of Mehelkuna who contributed so much to evolve a community-based approach and trained the author through their experience, actions and involvement in the participatory process.
Acharya, Rajeshwor

1986

\section{BIBLIOGRAPHY}

A Comparative Analysis of IRD Projects in Nepal with Special Reference to the Sagarmatha Project. Kathmandu: Center for Economic Development and Administration, Tribhuvan University.

\section{$\mathrm{ADB} / \mathrm{N}$}

1986

\section{APRÓSC}

1987

Bhave, Vinoba

Devkota, Padam La 1989 1988

A Decade of Small F armers Development Program in Nepal. Kathmandu: Small Farmers Development Division, Agricultural Development Bank of Nepal.

People's Participation in Rural Nepal. Workship Report. Kathmandu: Agricultural Projects Services Centre.

Satish Kumar (ed.), The Intimate and Ultimate. New Delhi: Elements Books. pp. 11-36.

aikie, M.P., J. Cameron and J.D. Seddan

The Struggle for Basic Needs in Nepal. Paris: Development Centre of the Organization for Economic Cooperation and Development.

Mehelkuna Community Development Project Document. Kathmandu: Health Development Project, Institute of Medicine, Tribhuvan University.

Voices from the Village: A Study of Training for Village Level Community Development Planning in K-BIRD Area. Surkhet: Kamali-Bheri Integrated Rural Development Project.

Community Participation in Forest Management: A Case Study of Nepal-Australia Forestry Project. Thokarpa. Kathmandu: Agriculture Development Council. 
Gilmour, D. R. Fisher 1991

Villagers, Forests \& Foresters: The Philosophy \& Practice of Community Forestry in Nepal. Kathmandu: Sahayogi Press.

Griffin, D.M.

1988

Innocents Abraod in the Forests of Nepal. Canberra: Anutech.

Integrated Development Systems (IDS)

1989

Swabalamban: An Approach. Kathmandu: IDS.

Korten, David C.

1988

Rural Development Planning: The Learning Approach: The Rural Participation Review. Ithaca: Rural Development Committee, Cornell University.

Tamang, D., G. Gill and G. Thapa (eds.)

1993

Indigenous Management of Natural Resources in Nepal. Kathmandu: HMG Ministry of Agriculture \& Winrock International.

Pandey, Devendra Raj 1989

"Experience in Technical Cooperation: Can We Hope for a Better Future?" Sambad. Bulletin, 1-24. Kathmandu: Integrated Development Systems.

Pradhan, Bharat Bahadur 1985

Integrated Rural Development Projects in Nepal: A Review. Kathmandu: International Centre for Integrated Mountain Development.

Shrestha, B.K.

1990

Characteristics of Successful Development Projects in Nepal. Discussion Session organised by Candadian Cooperation Office, Kathmandu.

RIDA

1989
Uphoff, Norman

Weiner, Paul J. 1989

\section{World Bank}

1988

Yadav, Ram Prasad 1990
"Problems Inhibiting Achievement of Broader People's Participation". Paper presented on People's Participation in Rural Development in Nepal. Kathmandu: Agricultural Projects Services Centre.

"Source-force" and the Medical Profession. Social Science and Medicine, 29(5). MacMillan.

Nepal: Policies for Improving Growth and Alleviating Poverty. Washington, DC: The World Bank.

"Rural Development and Resource Management in the Context of Basic Needs". Paper presented at the seminar workshop on "Planning Policies, Strategies in Meeting Basic Needs Targets". Kathmandu: Centre for Economic Development and Administration, Tribhuvan University. 